\title{
NASZA - WASZA ZAGLADA. MIZRACHIM WOBEC IZRAELSKIEJ PAMIĘCI O SZOA I POLSKICH PRZESTRZENI NAZNACZONYCH ${ }^{1}$
}

\author{
JAGODA BUDZIK ${ }^{2}$ \\ (Uniwersytet im. Adama Mickiewicza w Poznaniu)
}

Słowa kluczowe: Zagłada, pamięć zbiorowa, Mizrachim, Izrael Keywords: Holocaust, collective memory, Mizrachim, Israel

\begin{abstract}
Abstrakt: Jagoda Budzik, NASZA - WASZA ZAGŁADA. MIZRACHIM WOBEC IZRAELSKIEJ PAMIĘCI O SZOA I POLSKICH PRZESTRZENI NAZNACZONYCH. „PORÓWNANIA” 2 (21), 2017, S. 243-258. ISSN 1733-165X. Tekst ma na celu analizę różnorodnych postaw wobec izraelskiego dyskursu zagładowego, prezentowanych przez izraelskich pisarzy i artystów określanych jako Mizrachim. Jak twierdzę, choć nie są oni związani z Szoa biograficznie, stanowią część pozagładowych generacji. Idea spoglądania na izraelskie konfrontacje z pamięcią o Zagładzie, choć już od dawna zakorzeniona w naturze tego doświadczenia, w tym konkretnym przypadku wskazuje dodatkowo na skalę wpływu, który temat Szoa wywiera na całe społeczeństwo. Stąd analizowane przeze mnie postawy są nierzadko skrajne: od akceptacji i prób zaadaptowania pamięci o Zagładzie jako części własnej tożsamości po krytykę statusu przynależnego tej pamięci w Izraelu jako wykluczającego i opresyjnego wobec tych, którzy nie mogą się z nią identyfikować. Niektórzy twórcy próbują także na nowo negocjować granice publicznego dyskursu i włączyć do niego również własną perspektywę.
\end{abstract}

Abstract: Jagoda Budzik, OUR - YOUR HOLOCAUST. MIZRACHI AUTHORS OF THE THIRD POST-HOLOCAUST GENERATION TOWARD POLISH LANDSCAPES. "PORÓWNANIA" 2 (21), 2017, P. 243-258. ISSN 1733-165X. The paper aims at analyzing the variety of attitudes shown by the Israeli writers and artists of Mizrachi origins towards Israeli Holocaust discourse. I argue that although most of the authors are not connected to the Holocaust biographically, they

1 Praca naukowa finansowana ze środków budżetowych na naukę w latach 2014-2018 jako projekt badawczy „Erecszam - kraj tam. Strategie konstruowania obrazu Polski w literackich i pozaliterackich tekstach kultury o Zagładzie izraelskich autorów trzeciego pokolenia" w ramach programu pod nazwą "Diamentowy Grant".

2 E-mail: jagoda.budzik@wp.pl 
also may be considered as part of what is called post-Holocaust generations. The concept of describing the Israeli authors' confrontation with the Holocaust memory in terms of post-Holocaust generations is deeply rooted in the specific nature of this experience. In this particular case it might be perceived - above all - as a symptom of influence the Israeli Holocaust discourse has on the whole society. Therefore, the attitudes I describe range from acceptance expressed by attempts to adapt the memory of Shoah as a part of one's own identity to criticizing the status of Holocaust narrative in Israel as exclusive and oppressive towards those who cannot identify with it. Some of the artists try also to renegotiate the boundaries of the public discourse and to include their own perspective into it.

Etgar Keret swoje opowiadanie zatytułowane Buty rozpoczyna w następujący sposób:

Na Dzień Zagłady pojechaliśmy z nauczycielką Sarą do Domu Pamięci Żydów z Wołynia i czułem się strasznie ważny. Wszystkie dzieci w klasie były z Iraku, tylko ja - nie, i mój kuzyn, i jeszcze taki jeden, Drukman, ale tylko ja miałem dziadka, który zginął w czasie Zagłady (Keret 98).

Ten otwierający fragment, grupujący uczestników szkolnej wyprawy według klucza biograficznego, pozornie nie ma większego znaczenia dla dalszej akcji opowiadania o chłopcu, który opacznie interpretując nakaz przewodnika w Domu Pamięci, aby nie używać niemieckich produktów, uznaje przywiezione z Niemiec adidasy za drogę kontaktu ze zmarłym podczas Zagłady dziadkiem. Jeśli jednak zechcemy spojrzeć na przywołane opowiadanie jako na tekst ukazujący aktywne w Izraelu mechanizmy pamiętania o Szoa (zarówno te instytucjonalne, jak i występujące u ocalałych z Zagłady i kolejnych pokoleń ofiar), fragment ten $\mathrm{w}$ istocie wstępnie prezentuje podział ról i rozkład akcentów w ramach rytuałów zbiorowego pamiętania oraz sygnalizuje hierarchizację, która decydowała o mechanizmach działania izraelskiej wspólnoty pamięci. Z jednej strony wskazuje, że pamięć o wydarzeniach Zagłady stała się doświadczeniem powszechnym, z drugiej - sugeruje, że pod powierzchnią kolektywnej narracji tożsamościowej kryje się inna opowieść, w której swoje znaczenie zmieniają wyrażenia takie jak pustka i tożsamościowa luka. Opowieść o mniejszości, której pamięć kształtowana jest na wzór pamięci większości, która swoją tożsamość podporządkować musiała nieprzynależnym jej dotąd - lub przynależnym wyłącznie częściowo - kulturowym wzorcom. I choć może się zdawać, że na przestrzeni trzech pokoleń po Szoa w ramach społeczności izraelskich Żydów udało się osiągnąć to, co określane jest mianem „wspólnej tożsamości”, również w kontekście pamięci o Zagładzie, nie ulega wątpliwości, że projekt ten wyzwolił szereg dodatkowych mechanizmów, które pod znakiem zapytania stawiają rozpatrywanie go w kategoriach jednoznacznego sukcesu.

Historia skomplikowanej relacji Mizrachim i izraelskiego dyskursu o Zagładzie, otwierając nową perspektywę refleksji nad mechanizmami protetycznej pa- 
mięci (Skalska 343), prowokuje zarazem szereg pytań i wymaga uwzględnienia dodatkowych okoliczności, takich jak zasady kształtowania kolektywnej tożsamości na kolejnych etapach rozwoju państwa oraz szczególną dla tego procesu rolę Zagłady. Każe zwrócić uwagę z jednej strony na hegemoniczność narracji o Szoa, podkreślając wpisany $\mathrm{w}$ nią podział, $\mathrm{z}$ drugiej - na jej pozycję fundamentu zbiorowej tożsamości. Wyostrza zakres działania mechanizmów ujednolicania kolektywnej pamięci i zwraca uwagę na ich konsekwencje. Aby jednak możliwie najpełniej zrozumieć podstawy takiego a nie innego ulokowania przedstawicieli grupy Mizrachim w dyskursie o Szoa i wyznaczanym przez niego w Izraelu polu semantycznym, stanowiącym punkt wyjścia dla budowania tożsamości, uporządkować należy kilka istotnych kontekstów.

Izraelskie społeczeństwo, zasadniczo dzielone na społeczność żydowską i palestyńską, w istocie mieści w sobie znacznie bardziej rozbudowaną sieć podziałów i antagonizmów. Drugą w kolejności linię podziału wśród izraelskich Żydów wyodrębnia podział na Mizrachim (od mizrach - 'wschód', zazwyczaj umownie łączonych z Żydami sefardyjskimi), kojarzonych z tym, co wschodnie, prymitywne i dalekie od ideologicznych fundamentów Państwa Izrael i Aszkenazyjczyków, łączonych z tym, co zachodnie ${ }^{3}$, postępowe i leżące u fundamentów państwa. Ten podział, jakkolwiek upraszczający (bo nierespektujący znaczących różnic między Żydami z różnych państw Bliskiego Wschodu i Afryki Północnej, a zatem w istocie odmiennych kręgów kulturowych etc.), odgrywał kluczową rolę w procesie dystrybucji ról społecznych i udzielania poszczególnym grupom głosu w tworzeniu narodowych mitów i kolektywnej historii.

Od przełomu lat czterdziestych i pięćdziesiątych XX wieku, a zatem od samego początku kształtowania się Państwa Izrael, na jego teren zaczęto masowo sprowadzać Żydów z obszarów Północnej Afryki i Bliskiego Wschodu (DellaPergola 21). Etap ten był najczęściej naznaczony traumą pobytu $\mathrm{w}$ obozach przejściowych (tzw. „Ma'abarot”), w których Mizrachim przetrzymywani byli, nierzadko latami, w trudnych do zniesienia warunkach. Część z nich osiedlano także na terenach uprzednio zamieszkiwanych przez Palestyńczyków (Shochat 1999: 34-36). Powstałe $\mathrm{w}$ ten sposób heterogeniczne społeczeństwo od samego początku podlegało hierarchizacji, ufundowanej na objawiającej się na wielu poziomach (między innymi ekonomicznym i kulturowym) przewadze Aszkenazyjczyków. Mizrachim, biedni

3 W istocie określenie to odnosi się do przedstawicieli tej grupy Żydów, która w średniowieczu osiedliła się w Dolinie Renu, a następnie rozprzestrzeniło się, wraz z aszkenazyjską kulturą, na tereny Polski, Litwy, Rosji i Ukrainy. W omawianym kontekście określenie „Aszkenazyjczyk" nie odwołuje się bezpośrednio do reprezentantów kultury aszkenazyjskiej (którą, jako element diasporowej tożsamości, syjonizm odrzucał), a raczej do przynależnych jej terenów, na których narodził się syjonizm i z których pochodzili założyciele Państwa Izrael. Określenie "Żydzi europejscy” jest w tym wypadku znacznie mniej precyzyjne, bowiem np. Żydzi bałkańscy i śródziemnomorscy reprezentowali kulturę sefardyjską, które to rozróżnienie dało o sobie znać w pierwszych dekadach kształtowania izraelskiej narracji o Zagładzie. 
i postrzegani jako prymitywni, stali się obiektem różnego rodzaju wykluczeń, często na tle rasistowskim ${ }^{4}$.

Sytuacja ta znajdowała wyraźne odbicie na gruncie państwowej ideologii. To właśnie Żydzi wywodzący się z kultury aszkenazyjskiej stali na czele syjonistycznych ruchów zakładających państwo, oni decydowali o jego kształcie ${ }^{5}$ i panującej ideologii, oni pisali historię i projektowali kolektywną pamięć. Na tym tle chętnie podkreślano także różnice $w$ motywacjach przybywania do kształtującego się państwa właściwych Aszkenazyjczykom i Mizrachim. O ile bowiem pierwsi w większości mieli robić to z przyczyn ideologicznych i chęci budowy nowego Izraela, o tyle drugim przypisywano kierowanie się głównie pragnieniem poprawy warunków życia. W myśl tej różnicy nie mogli zatem zaliczać się do grona „prawdziwych syjonistów" ${ }^{\prime \prime}$, co więcej - to właśnie europejskiemu syjonizmowi zawdzięczali ratunek przed rozpaczliwie złą sytuacją bytową i brutalnym traktowaniem, których doświadczali w krajach arabskich (Shochat 1999: 14). Z tej perspektywy pisana była również historia Zagłady, która przez pierwsze dekady istnienia państwa pod wieloma względami, w większości wpisującymi się w szerszy mechanizm „odrzucenia diaspory”, była obwarowana wieloma ideologicznymi ograniczeniami. Nie uwzględniała ona Żydów z Tunezji i Libii jako ofiar nazistowskich działań, choć Żydzi tunezyjscy znajdowali się pod niemiecką okupacją przez około pół roku i w tym czasie zmuszani byli do niewolniczej pracy w ciężkich warunkach, natomiast kilkuset Żydów z Libii umieszczonych zostało w obozach pracy przymusowej w Libii i Tunezji, skąd przewieziono ich do obozów we Włoszech, a część z nich trafiła stamtąd do Auschwitz i Bergen-Belsen (Jablonka 84).

W ramach oficjalnej narracji o Zagładzie nieobecność ta stała się szczególnie zauważalna w kontekście przełomu, zapoczątkowanego w latach 1961-1962 przez toczący się wówczas w Jerozolimie proces Adolfa Eichmanna. Wydarzenie, którego przebieg i skutki wykroczyły daleko poza ramy prawnej procedury, stało się także okazją do zaobserwowania podziału w ramach izraelskiej wspólnoty pamięci. Jak pisze Hana Jablonka, po obwieszczeniu Ben Guriona, że pojmano Eichmanna, i przewiezieniu zbrodniarza do Izraela pilnowali go wyłącznie strażnicy pochodzący z Północnej Afryki i Bliskiego Wschodu jako ci, „których rodziny nie doświadczyły osobiście okropieństwa nazistowskiej Szoa i którzy w związku z tym nie budzą obaw co do ewentualnego przekroczenia swoich kompetencji i dokonania samosądu na naziście" (Jablonka 94). Również bezpośredni wykonawca wyroku na

4 Jednym z utartych określeń na przedstawicieli tej grupy było pochodzące z jidysz określenie "Szwarces”, bezpośrednio nawiązujące do ciemniejszego niż u Aszkenazyjczyków koloru skóry Mizrachim (Jablonka 17).

5 Ustalonym już przez Teodora Hertzla na wzór kapitalistyczno-demokratycznego państwa Zachodu czy, jak marzył Ben Gurion, „Szwajcarii Bliskiego Wschodu” (Shochat 1999: 43).

6 O stosunku Żydów sefardyjskich do syjonistycznej ideologii pisze między innymi Ella Shochat, zob. Shochat 1999. 
Adolfie Eichmannie, jemeński Żyd Szalom Nagar, wybrany został zgodnie z kluczem nieaszkenazyjskiego pochodzenia. Na tle procesu zauważalny stał się jeszcze jeden mechanizm. Wybór mających zeznawać ocalałych, dokonany przez prokuratora Gideona Hausnera, wpływał na wyłaniający się z procesu obraz Zagłady jako doświadczenia, które dotknąć miało nie tyle nawet Żydów europejskich, ile wyłącznie Żydów aszkenazyjskich. Pominięci zostali bowiem nie tylko Żydzi z Tunezji i Libii, ale i - niemal całkowicie - Żydzi bałkańscy. Jedynym spośród nich, którego zaproszono do złożenia zeznań, był pochodzący z Grecji Icchak Nechama.

Jeśli przyjąć, że proces Eichmanna był wydarzeniem, które na długie lata ukształtować miało zbiorowe pamiętanie o Zagładzie, z pewnością stanowił on impuls do zaistnienia $\mathrm{w}$ izraelskiej zbiorowej pamięci nowych tendencji. Jablonka postrzega okres po procesie Eichmanna jako czas, w którym tendencja wykluczania Mizrachim z kolektywnej pamięci stopniowo ustępowała. Symbolicznego zrównania pozycji aszkenazyjczyków i Mizrachim upatruje w zorganizowanej przez Muzeum Kibucu Bojowników Getta w czterdziestą rocznicę zakończenia procesu wystawie Szisza milion kategorim. Medinat Israel neged Adolf Eichmann („Sześć milionów oskarżycieli. Państwo Izrael przeciwko Adolfowi Eichmannowi"), która w prezentowaną opowieść o Zagładzie włączała już historię Żydów z Libii i Tunezji oraz pozostałych Żydów nieaszkenazyjskich (Jablonka 97).

Fakt ten niewątpliwie wpisuje się $\mathrm{w}$ tendencję przenikania Szoa do kolejnych sfer życia publicznego, połączonego z jej otwieraniem się na nowe narracje. Wraz ze wzrostem zbiorowego przekonania o utopijności założeń syjonizmu (w tym kulturowego melting pot) oraz z postępowaniem procesów globalizacyjnych zaistniała pilna potrzeba odnalezienia innego środka spajającego - a zatem umacniającego - społeczeństwo. Jednocześnie Zagłada, wyraźniej niż kiedykolwiek przedtem, przybrała rolę argumentu usprawiedliwiającego podejmowane przez Izrael decyzje polityczne: „" «Auschwitz», które dotąd było tylko historią, minioną rzeczywistością, symbolem i metaforą trudną do wyobrażenia i opisania - stało się wygodną figurą narracyjną, którą można było zastosować do opisu skrajnie odmiennych wydarzeń historycznych" (Zertal 217). W ten sposób pamięć o Zagładzie została ostatecznie ukonstytuowana jako powszechnie obowiązująca i odnosząca się do różnych dziedzin. Stała się źródłem powszechnie stosowanego zabiegu przedstawiania Palestyńczyków (lub ogólniej, Arabów) jako nowych nazistów - „pamięcią na wszystkie pory roku", jak pisze Idith Zertal (Zertal 217). Tożsamość ofiary, mająca uzasadniać militarne decyzje państwa, jak również sam fakt jego istnienia, pełniła też istotną funkcję unifikującą, wymagając zarazem utworzenia kolektywnej, jednolitej żydowskiej historii, której punktem centralnym byłyby prześladowania okresu diaspory.

Wzorcem dla tej narracji o prześladowaniach była właśnie Zagłada, częstokroć przedstawiana jako kumulacja wymierzonych w Żydów - zarówno w Europie, jak i na Bliskim Wschodzie - aktów zbiorowej agresji. Ella Shochat w odniesieniu do 
takich zasad konstruowania historycznej narracji w ramach oficjalnego izraelskiego dyskursu pisze:

Prześladowania Żydów Sefardyjskich postrzegane są głównie jako zapowiedź Zagłady Żydów [europejskich - J.B.] W ramach tego paradygmatu, trauma wywołana ludobójczymi praktykami nazistów jest upraszczająco projektowana na doświadczenia Żydów z krajów muzułmańskich i na konflikt izraelsko-palestyński (Shochat 2006: 214).

Upraszczające wpisanie doświadczenia bliskowschodnich Żydów w fundamentalną dla współczesnego Izraela narrację o zakończonych Zagładą prześladowaniach z czasu diaspory wyzwoliło u młodych Mizrachim kilka rodzajów postaw, których przykłady odnaleźć można w pochodzących z ostatnich dekad tekstach kultury. Powstała $w$ ten sposób galeria reakcji zmusza do podania w wątpliwość konstatacji Jablonki o ostatecznym sukcesie związanym z zaszczepieniem u Mizrachim „izraelskiego DNA”, a także o realnej szansie na to, by wszystkie grupy na równych prawach uczestniczyły w procesie pamiętania:

Do "trzeciego pokolenia” Mizrachim Zagłada przeniknęła już jako oczywistość, jako centrum tożsamości kolektywnej, tożsamości bez względu na indywidualną i rodzinną biografię. Tożsamości otwartej na wyzwania i gotowej na przesunięcia, którą można odrzucić, a nawet uczynić tematem żartów. Członkowie trzeciego pokolenia, urodzeni w Izraelu, wnukowie imigrantów z lat 50. i 60., Izraelczycy ponad wszelką wątpliwość, pewni swojej pozycji, są pełnoprawnymi uczestnikami procesu kształtowania pamięci o Zagładzie i tymi, którzy rozpowszechniają przyjęte i ugruntowane wzorce pamiętania (Jablonka 297).

Z tekstów kultury, w których opisywane są jednostkowe przykłady konfrontacji Mizrachim z mechanizmami i rytuałami pamięci o Zagładzie, za których swoistą kumulację uznać można podróż do Polski ${ }^{7}$, wyłania się obraz znacznie bardziej złożony. Choć „upowszechnienie pamięci”, o którym pisze Jablonka, również odciska swój ślad na funkcjonujących w kulturze stanowiskach w tej sprawie, teksty te pozwalają na wyodrębnienie wielu więcej postaw przyjmowanych przez Mizrachim drugiego i trzeciego pokolenia w procesie kształtowania swojej izraelskiej tożsamości. Powodem tego stanu rzeczy jest wielość (a także: wielokierunkowość) prze-

7 Figura Polski jest w rozważaniach nad izraelską pamięcią o Szoa kluczowa, funkcjonuje ona bowiem w ramach dychotomicznego podziału na „kraj śmierci” (Polska) i „kraj odrodzenia” (Izrael). Na mocy tej utrwalonej w oficjalnym dyskursie polaryzacji wizyta w Polsce z jednej strony stanowi niezbędny element budowania pamięci o Zagładzie, z drugiej, zawłaszczana przez dyskurs o Szoa, może stanowić szczególnie silne uzasadnienie dla konieczności istnienia Państwa Izrael. Obydwa wyrażenia "kraj Zagłady” i „kraj odrodzenia” stanowią nawiązanie do silnie obecnego w języku hebrajskim i w izraelskiej kulturze sformułowania "Mi-szoa le-tkuma” - „Od Zagłady do odrodzenia", które łączy wydarzenia Szoa z założeniem Państwa Izrael. 
mian, którym podlegała izraelska narracja tożsamościowa, ale i główny nurt izraelskiej literatury i kultury. Podczas gdy na pewnych obszarach pozycja Zagłady jako tożsamościowego fundamentu uległa umocnieniu, izraelska kultura otworzyła się na nieobecne dotąd na jej obszarze opowieści o doświadczeniach grup mniejszościowych ${ }^{8}$ (Abramovich 17, Oppenheimer 336).

W ten sposób spotkanie przedostającej się na powierzchnię opowieści o doświadczeniu nieaszkenazyjskiej części społeczeństwa z silnie obecną w izraelskiej rzeczywistości kolektywną pamięcią o Szoa było nieuniknione, a jego rozwój okazał się przebiegać wielokierunkowo. Każda z postaw przyjmowanych przez twórców stanowi bezpośredni wynik tego spotkania i związanego z nim konfliktu między potrzebą przynależności do kolektywnej narracji tożsamościowej a świadomością własnego pochodzenia. Każda jest jednocześnie oznaką przemian, które zaszły w ramach izraelskiej narracji o Zagładzie i zasadach jej funkcjonowania w publicznym dyskursie, oraz symptomem obecnego na niemal każdym poziomie izraelskiej tożsamości konfliktu między założeniami oficjalnej narracji a osobistym jej doświadczaniem.

\section{Identyfikacja}

Podkreślana przez Jablonkę tendencja wzrostu identyfikacji młodych Mizrachim z dyskursem o Zagładzie jest konsekwencją innego procesu. Wyraźnie zauważalny od końca lat siedemdziesiątych przełom w opowieści o tym, czym jest żydowska tożsamość, polegał na uczynieniu Szoa figurą egalitarną - z założenia dostępną w równym stopniu każdemu przedstawicielowi żydowskiej części społeczeństwa, ułatwiającą zarazem identyfikację z doświadczeniem Zagłady bez względu na rodzinną biografię.

Dudu Mayan, założyciel Teatru Akko, współtwórca (wraz z Madi Mayan) legendarnego spektaklu Arbeit Macht Frei vom Toitland Europa, stanowiącego jedną $\mathrm{z}$ bodaj najpełniejszych refleksji na temat natury kolektywnej pamięci o Szoa w Izraelu (Cimerman 279), pochodzi z Maroka. W poświęconym Arbeit Macht Frei... filmie Aszera Tlalima o znamiennym tytule Al tig'u li ba-Szoa („Nie ruszajcie mojej Szoa”, 1994), w części zatytułowanej „Co Marokańczykowi do Zagłady?” Mayan, tłumacząc powody swojego zaangażowania w refleksję nad kolektywną pamięcią, podkreśla, że dorastanie w izraelskim społeczeństwie zaszczepiło w nim dokładnie taki sam związek z historią Szoa, jak u wszystkich innych: "Jestem ocalałym z Zagłady $w$ takim samym stopniu. Jestem tym dotknięty $w$ tym samym stopniu. Mieszkam w tym samym kraju, uczyłem się w tych samych szkołach co wszyscy.

8 O wielokierunkowości zmian w izraelskim dyskursie tożsamościowym, przechodzącym ze struktury monolitycznej w neomonolityczną pisał Dan Bar-On (zob. Bar-On). 
Większość moich przyjaciół to absolwenci akademii ocaleństwa" (Tlalim 1994). Mayan konfrontuje się co prawda ze swoimi korzeniami, odwiedzając dom rodzinny w Casablance, ale tym, co najsilniej go konstytuuje, jest pamięć o Zagładzie, a raczej doświadczenie jej nieustającej obecności w izraelskim dyskursie. Jak pisze Liat Sztejr-Liwni, jego przypadek jest przykładem zerwania z polaryzacją między zbiorową pamięcią Aszkenazyjczyków i Mizrachim (Sztejr-Liwni 219), jednak w istocie należałoby stwierdzić, że wskazuje on przede wszystkim na intensywność, z jaką Zagłada obecna była w jego życiu i budowała jego świadomość.

Podobne wrażenie sprawia bohater powieści Yosiego Avni-Leviego Szirat hachata'im („Pieśń grzechów”), która - choć budzi wątpliwości i niepokój na poziomie zarówno fabuły, jak i konstrukcji - stanowi interesujący przykład sprzężenia tożsamościowej narracji Mizrachim z wszechobecną, nierzadko infantylizowaną pamięcią o Zagładzie. Boaz, młody Izraelczyk o korzeniach iracko-kurdyjskich, obsesyjnie interesuje się Zagładą (w powieści zresztą wielokrotnie fetyszyzowaną), bez reszty oddając się badaniu historii łódzkiego getta. Gdy dowiaduje się o konkursie, w którym nagrodą jest stypendium badawcze w Polsce, w jego głowie pojawia się myśl: „To nie wyścig o milion! To wyścig o sześć milionów! [...] Ja! Boaz oniemiał z zachwytu i ze wzruszenia. Jego brzuch, jak miech, unosił się i opadał. Ja pojadę! Ja!" (Avni-Levi 2010: 10). Choć częstokroć przywołuje on w myślach wspomnienia z dzieciństwa w biednym, zasiedlonym przez kurdyjskich Żydów moszawie, większość z nich dotyczy wydarzeń wiążących się z pamięcią o Zagładzie, emitowanymi w telewizji w Dzień Pamięci o Szoa filmami, które nieustannie ogląda jego matka, zagładową metaforyką, która przeniknęła do języka jego rodziców, jednoznacznie wskazując, które doświadczenie zajmuje w jego pamięci silniejszą pozycję (Avni-Levi 2010: 36-37). Skala tego procesu, a zarazem kolektywność doświadczenia zagładowej postpamięci $\mathrm{w}$ pełni uzewnętrznia się $\mathrm{w}$ chwili przyjazdu bohatera do Polski. Przejeżdżając po raz pierwszy w życiu przez Warszawę, Boaz konfrontuje się ze wszystkim, do czego dążył przez lata studiów nad Zagładą i prób się do kolektywnej narracji: „Oczarowany zerkał na zawieszone ponad drogami tablice: Lublin. Łódź. Chełm. Już tu kiedyś byłem, dziwna myśl przebiegła przez jego głowę. Wszyscy już tu byliśmy" (Avni-Levi 2010: 41). Tak silne u Boaza pragnienie konfrontacji z polskimi przestrzeniami oraz przymus zgłębiania zagładowej historii w znacznym stopniu determinowane są przez palącą potrzebę przynależności.

Tego rodzaju szczególny związek łączy z zagładowym dyskursem także bohatera innej powieści Leviego. W powieści Isz le-lo cel („Człowiek bez cienia”, 2007) autor opisuje następującą sytuację z czasów dzieciństwa Jonatana, głównego bohatera: nauczyciel historii prosi, aby każdy uczeń opisał zagładowe dzieje swojej rodziny, chłopiec z przerażeniem odkrywa jednak, że nikt z jego bliskich nie doświadczył Zagłady. Wtedy postanawia wymyślić postać dalekiej ciotki Batszewy,

9 Wszystkie fragmenty omawianych tekstów kultury podaję we własnym tłumaczeniu. 
która razem z rodziną osiadła przed wojną w Sewastopolu i w 1943 roku została zamordowana przez nazistów (Avni-Levi 2007: 89). Podczas prezentacji przygotowanych przez uczniów historii Jonatana dręczy tylko jedna myśl:

Tak bardzo chciał być jednym z nich! Tak bardzo chciał mieć dziadków i babcie, którzy zginęliby w Treblince, ja k nale ż y [podkr. J.B.]! W mgnieniu oka wymyślił więc historię drogi ciotki Batszewy na Krym, a stary nauczyciel Jeszajahu Huchman zsunął okulary i powiedział: „Wspaniały, tragiczny, żydowski los”. Przetarł okulary i spojrzał na niego wzrokiem innym niż kiedykolwiek przedtem (Avni-Levi 2007: 90).

Opisana wyżej hegemonizacja izraelskiego dyskursu tożsamościowego w przypadku wielu młodych Żydów o korzeniach bliskowschodnich skutkuje szczególnym rodzajem tożsamościowej pustki. Pustki protetycznej, wywołanej bowiem nie faktyczną (jak w wypadku niektórych potomków ofiar Zagłady) świadomością utraty w Szoa części rodziny, ale spowodowanej właśnie przez jej brak. Świadomości, która staje się w tym wypadku przepustką do możliwości postrzegania siebie jako pełnoprawnego członka izraelskiego społeczeństwa. Co znamienne, sytuacja ta sprawia, że wielokrotnie uczestnictwo młodych Mizrachim w rytuałach pamięci jest obciążone dalece większym znaczeniem niż w przypadku ich aszkenazyjskich rówieśników, a przestrzeń Polski, której granice w tym wypadku wyznaczają miejsca naznaczone Zagładą, w szczególnym stopniu pozwala uzewnętrznić tę zależność.

Itamar Tobi Taharlew o wizycie w Polsce pisze jako o koniecznym do przebycia dla Mizrachim procesie „aszkenizacji” (Taharlew, źródło elektroniczne). Wycieczka, w której uczestniczy, składa się z licznej grupy Mizrachim i tylko kilkorga aszkenazyjskich uczniów, którzy nie są przejęci tym, gdzie się znajdują. Autor jest jednak zdania, że większe zaangażowanie Mizrachim w poznawanie historii Zagłady jest formą pozyskiwania tożsamości, którą Aszkenazyjczycy posiedli już w chwili narodzin. Taharlew jest zarazem głęboko świadom podrzędnej pozycji, którą zajmuje w społeczeństwie jego grupa, tłumacząc to w następujący sposób:

Być może jest to związane również z tym, że Mizrachim występują w Izraelu w roli Żydów z diaspory. Jak twierdzi uczony Amnon Raz Krakotzkin, ten sam mechanizm, który doprowadził do odrzucenia diaspory, teraz obrócił się przeciwko Mizrachim, którzy postrzegani jako religijni, zyskują wizerunek diasporowy, a nie nowoczesny (Taharlew, źródło elektroniczne).

Taharlew jest krytyczny wobec izraelskiej polityki konstruowania homogenicznej zbiorowej tożsamości na warunkach narzucanych przez większość, ale zarazem zdaje sobie sprawę z tego, że tylko taką drogą stanie się równoprawną częścią społeczeństwa i z nadzieją czeka na kolejne oznaki swojej „,aszkenizacji”. 
Jackie Feldman, pisząc o organizowanych przez ministerstwo edukacji pielgrzymkach do Polski, rozpatruje je w kategoriach rytuału, za sprawą którego uczestnicy wycieczki symbolicznie odtwarzają akt ocalenia z Szoa i z pozyskaną w ten sposób tożsamością ocalałych wracają z kraju Zagłady do kraju odrodzenia (Feldman 255). Nietrudno zauważyć, że w wypadku nieaszkenazyjskich uczestników wycieczek mówić można o dodatkowym rytuale przejścia - w ich wypadku wizyta $\mathrm{w}$ Polsce stanowi przepustkę do osiągnięcia pełni tego, co powszechnie określone zostało mianem izraelskiej tożsamości. Jednak Polska stanowi zarazem przestrzeń jedynie pozornego przejścia. Są bowiem powody, aby sądzić, że tego rodzaju unifikujące tożsamość dążenia do możliwie najpełniejszej przynależności najczęściej przynosić mogą jedynie pozorne efekty.

\section{„Co ma Mizrachi do Zagłady?"}

To pytanie, biorąc pod uwagę tezę o "Zagładzie jako elemencie izraelskiego DNA", zaskakująco regularnie pojawia się w opowieściach (niezależnie od ich proweniencji gatunkowej) młodych Mizrachim przedstawiających czy - co równie znaczące - usprawiedliwiających swoje zainteresowanie pamięcią o Szoa, tak jak w nieco zmienionej formie pojawiło się ono w omówionym fragmencie filmu Tlalima. Bohater Szirat ha-chata'im Avni-Leviego, choć sam pewien swoich związków z tematem Zagłady, nieustannie zderza się z wypowiedziami kwestionującymi jego prawo do poświęcania się badaniom nad Szoa. Przyjmują one formę drwin (współlokatorka nadająca bohaterowi związane z jego zainteresowaniami pseudonimy, takie jak „Umschlagplatz” czy „Sześć milionów”, Avni-Levi 2012:11), wywołanych autentycznym zdumieniem pytań (przewodniczący komisji konkursowej, Avni-Levi 2012:31, polska ukochana, Avni-Levi 2012: 292) czy w końcu otwarcie formułowanych zarzutów. Podczas zmagań o stypendium konkurent Boaza, próbując zdyskredytować jego kandydaturę, konsekwentnie posługuje się kryterium pochodzenia:

Są tam rozsiane kości sześciu albo siedmiu moich ciotek. To, co zostało z mojej babci, teraz służy do uprawy kapusty albo rzepy. Jeśli ktoś powinien się tym interesować, to ja, a nie ty. [...] Wy, Mizrachim, chcecie poczuć się częścią aszkenazyjskiej, rządzącej elity, więc przejęliście sobie właśnie kult Szoa (Avni-Levi 2010: 26).

Również Taharlew w cytowanym wyżej tekście opisującym jego szkolną podróż do Polski i przygotowania do niej wspomina:

Jedno z moich najmocniejszych wspomnień pochodzi z etapu przygotowań. $\mathrm{W}$ ramach programu musieliśmy spotkać się z ocalałym z Zagłady. [...] Opowiadał o jakimś ży- 
dowskim rabinie, jak mówił, nadal żyjącym w Izraelu, który sprzedawał Żydów za pieniądze i nadal za to pokutuje. [...] Ale nie gorzej niż to pamiętam, że zapytał, zwracając się bezpośrednio do mnie i do Ejnat Barzani [obydwoje mieli ciemniejszy niż reszta, złożonej w większości z Mizrachim grupy kolor skóry - J.B.]: „Zaraz, wy nie jesteście Aszkenazyjczykami. Po co jedziecie do Polski? Co wam do Zagłady?” (Taharlew , źródło elektroniczne).

Choć udział Mizrachim w powszechnej narracji tożsamościowej, opartej na pamięci o Szoa, stał się faktem, nadal jeszcze budzi zdziwienie i sprzeciw. Stan ten skutkuje niekiedy zwiększeniem starań o zbliżenie się do doświadczenia mającego fundować zbiorową tożsamość (jak w wypadku postaci Boaza w Sziratha-chata'im, zob. Avni-Levi 2010: 12), jednak częstokroć prowokuje też mechanizmy radykalnie odmienne.

\section{Odrzucenie aszkenazyjskości}

Jeśli prezentowaną w opisanych wyżej sytuacjach, bezwarunkową „chęć przynależności” uznamy za jeden z biegunów spektrum postaw możliwych do zaobserwowania w kulturowych reprezentacjach omawianego tożsamościowego procesu, to drugi z nich należy wyznaczyć w miejscu, gdzie kumulują się postawy bazujące na radykalnym odcięciu się od hegemonicznej narracji i zdecydowanym sprzeciwie wobec niej, a jednak nieustannie się do niej odwołujące. Jak wskazuje Feldman, w narastającej wszechobecności pamięci Szoa w systemie edukacji i innych płaszczyznach kształtowania kolektywnej podmiotowości wielu młodych Mizrachim zaczęło upatrywać kolejnego środka represji wobec mniejszościowych grup i otwarcie się jej sprzeciwiać (Feldman 74). Również ta tendencja szybko doczekała się swoich kulturowych reprezentacji. Przedstawione poniżej stanowiska artykułowane są w ramach odmiennych poetyk, podobnie jak osadzają się na różnych poziomach historii o aszkenazyjskiej dominacji i pozostawieniu Mizrachim na uboczu oficjalnej narracji, w istocie jednak zdają się stanowić integralne elementy tego samego doświadczenia.

Jak pisze Liat Sztejr Liwni, siłę napędową tego rodzaju postaw stanowi z jednej strony wykluczenie grupy mniejszościowej z pełnoprawnego doświadczenia izraelskiej tożsamości, z drugiej - własne doświadczenie kulturowej traumy towarzyszącej Mizrachim po przybyciu do nowo powstałego Izraela ${ }^{10}$, przymus nieustannej konfrontacji z tematem Zagłady i ciągłe poczucie braku przynależności. Ten stan

10 Ta sama kwestia stała się motorem napędowym dla analogii między doświadczeniem ofiar Zagłady i Mizrachim jako ofiar aszkenazyjskiej dominacji w Izraelu, która odzwierciedlenie znalazła również chociażby w języku za sprawą wyrażeń takich jak „Szoa kulturowa” czy „Aszkenacim”, od "Aszkenazim” (hebr. Aszkenazyjczycy) i „Nacim” (hebr. naziści) (por. Sztejr-Liwni 135-145). 
wyzwala tendencję wyraźnie zauważalną na polu związanej z Zagładą twórczości satyrycznej: „, [Mizrachim - J.B.] konfrontują się ze społeczeństwem, które zepchnęło na margines ich samych i ich związki z Zagładą, tworząc postaci Mizrachim, które wkraczają na «zakazany» teren, zastępując uświęconą pamięć Szoa humorem" (Sztejr-Liwni 128).

W wyprodukowanej przez grupę Ma Kaszur („Co z tego”) serii skeczy Polin („Polska”) dwaj Mizrachim, Josi i Josi, udają się w szkolną podróż do Polski. Postaci te są $\mathrm{W}$ widoczny sposób przerysowane, powielają utrwalone na temat Mizrachim stereotypy: mówią po hebrajsku z karykaturalnym akcentem, na tle innych uczestników wyjazdu sprawiają wrażenie prymitywnych i niezdolnych do podjęcia refleksji. Nie przejawiają najmniejszego zainteresowania tematyką Szoa, a Polska nie stanowi dla nich żadnego punktu odniesienia. Na udział w szkolnym wyjeździe zdecydowali się wyłącznie w nadziei na zdobycie względów blondwłosej Moran adorowanej przez nich koleżanki z klasy, do której nieudolnie się zalecają. Ta jednak $\mathrm{z}$ zaangażowaniem uczestniczy $\mathrm{w}$ patetycznych ceremoniach upamiętniania i jest zniesmaczona zachowaniem Josiego i Josiego.

Każda z prezentowanych w skeczach sytuacji podkreśla, przy wykorzystaniu różnych typów komizmu, barierę oddzielającą bohaterów od historii Szoa, która mimo że nie dotyczy ich bezpośrednio - ma, zgodnie z polityką edukacyjną, kształtować ich izraelsko-żydowską tożsamość. Ośmieszona zostaje idea pełnych patosu programów edukacyjnych, które na obydwu uczestnikach tej szczególnej „pielgrzymki" nie robią najmniejszego wrażenia, motywem przewodnim wszystkich scenek pozostaje jednakże brak łączności bohaterów z pamięcią, którą powszechnie się kultywuje.

Szczególnym na tym tle przykładem odrzucenia aszkenazyjskiej wersji historii jest powieść Josiego Sukariego Bengazi - Bergen-Belsen, jeden z niewielu literackich tekstów, które swoim tematem czynią żydowskie ofiary nazizmu pochodzące z Afryki Północnej. Autor opisuje w niej historię społeczności Żydów z Libii, którzy trafiają do obozu Bergen-Belsen, co wielu krytyków z uznaniem określiło jako „dopisanie kolejnego, ważnego rozdziału do historii Szoa". Jak jednak zauważa Batia Szimoni, to nie uzupełnienie istniejącej już opowieści jest głównym celem Sukariego, a n a pis a ni e jej od now a (Szimoni, źródło elektroniczne). W rozdziale opisującym przybycie Żydów z Libii do Bergen-Belsen niewątpliwie wyeksponowaną pozycję zajmuje opis ich spotkania z Żydami europejskimi, którzy odnoszą się do nowo przybyłych, z uwagi na ich pochodzenie i odmienny wygląd, z wrogością, traktując ich jako „obcych” (Sukari 278). Przemoc, której główna bohaterka, Silwana, doznaje ze strony aszkenazyjskich współwięźniów, stopniem swojej brutalności przewyższa w powieści Sukariego tę doświadczaną ze strony Niemców ${ }^{11}$.

11 Bengazi - Bergen-Belsen czytać można jako retrosepktywne nawiązanie do wątków z poprzedniej powieści Sukariego, Emilia we-melach ha-arec. Widuj („Emilia i sól ziemi. Spowiedź”, 2002). W tek- 
W ten sposób, co zaznacza również Szimoni, Sukari odwraca bieg znanej narracji, a opowiadana przez niego w rozdziale „Bergen-Belsen” historia ma, jak się zdaje, stanowić rodzaj preludium do powojennych losów Mizrachim w rzeczywistości aszkenazyjskiej dominacji, $\mathrm{w}$ istocie wpisując się nie tyle $\mathrm{w}$ nurt uzupełniania istniejącej narracji, ile otwierając przy jej pomocy refleksję nad powojenną sytuacją Żydów z Afryki Północnej i Bliskiego Wschodu w Izraelu.

„W państwie Aszkenaza czekają na gościa / nie na wspólnika” (Chasan 46) pisze w swoim wierszu Państwo Aszkenaza, otwierającym cykl o tym samym tytule, Roj Chasan. Choć proponowany przez członka grupy Ars Poetica ${ }^{12}$ obraz zakłada odcięcie się od aszkenazyjskości z całą radykalnością ${ }^{13} \mathrm{i}$ odnosi się raczej ogólnie do rzeczywistości społecznej i kulturowej niż wprost do kwestii kolektywnej pamięci, to przeniesione na ten grunt słowa poety mimowolnie zdają się diagnozować jeden z głównych problemów, jaki napotyka na drodze do upowszechnienia homogeniczna, izraelska tożsamość osadzona na fundamencie pamięci o Szoa.

\section{Zakończenie}

Niemożność zbudowania kolektywnej, izraelskiej tożsamości na jednej tylko wersji historii, konstruującej rodzaj pamięciowego monolitu, sygnalizował już ponad dwadzieścia lat temu przywołany przez Taharlewa Amnon Raz-Krakotzkin (Raz-Krakotzkin 114). Tymczasem tożsamość oparta w zasadniczym stopniu na pamięci o Zagładzie, niezależnie od zmieniającego się niekiedy wewnętrznego rozkładu akcentów, z założenia jest pamięcią homogeniczną. Jej stopniowe upowszechnienie i otwarcie dla grup niezwiązanych biograficznie z Szoa może zostać odczytane jako oznaka objęcia ramami hegemonicznej narracji również grup dotąd wykluczanych, niewątpliwie jednak jest to także dowód na skalę wpływu, jaki pamięć o Zagładzie wywiera na izraelską codzienność.

Silnie wybrzmiewające $\mathrm{w}$ filmie Tlalima pytanie o to, do kogo $\mathrm{w}$ istocie należy zbiorowa pamięć, a w tym wypadku zbiorowa pamięć o Zagładzie, sugeruje jednocześnie odpowiedź: pamięć kolektywna należy do państwa, jest przez nie kształtowana i z łatwością przeobrazić się może w polityczne narzędzie (por. Bartov 308). Przywołane teksty, prezentując szerokie spektrum postaw przyjmowanych przez

ście tym Sukari opisuje próby ukształtowania przez bohatera swojej tożsamości przez pryzmat doświadczeń i przekonań babki (tytułowej Emilii), w Bengazi... natomiast odnosi się do jej wojennych doświadczeń, sugerując tym samym interpretacyjny klucz pierwszej powieści.

12 Ars Poetica to zrzeszająca poetów o nieaszkenazyjskich korzeniach grupa, założona w 2013 roku przez poetkę Adi Kisar, zaliczaną do „nowej fali poetów Mizrachim”.

13 Dalej w wierszu Chasan pisze: „Nie płakałem po Kaniuku / Paliłem książki Natana Zacha / Nie obchodzę Dnia Niepodległości / dopóki nie założą mi państwa [...]" (Chasan 48), w innym wierszu dodaje: „Nie wyszliśmy z Egiptu / Niewolnikami byliśmy / i niewolnikami pozostaliśmy [...]” (Chasan 61). 
Mizrachim (zarówno na poziomie fabuły, jak i już na poziomie samego aktu twórczego), wskazują na nierozerwalny związek pamięci z polityką, w którym druga determinuje ostateczny kształt pierwszej. Dogodną przestrzenią obserwacji tego zjawiska jest Polska - fantazmatyczna przestrzeń nierozerwalnie związana w izraelskiej pamięci zbiorowej z pamięcią o Zagładzie. Niezależnie od tego, czy w geście sprzeciwu wobec hegemonicznej narracji jest celowo odrealniana, czy za sprawą postpamięci Szoa bliska i pozornie znana, nawet jeśli geograficznie odległa od rzeczywistego miejsca pochodzenia, daje ona świadectwo zasięgu izraelskiej polityki pamięci.

Ifaat Wajs w recenzji książki Jablonki zwraca uwagę na przywołane przez nią słowa ostrzeżenia, które już w latach osiemdziesiątych, a zatem okresie, w którym po przewrocie politycznym ${ }^{14}$ najsilniej rozwijał się projekt żydowsko-izraelskiej tożsamości opartej na pamięci o Szoa, wypowiedział Uriel Tal:

Ministerstwo Edukacji kieruje się nie tylko celami edukacyjnymi, ale wręcz skrajnie nacjonalistycznymi. [...] Jako związani z tematem, musimy podkreślać nasz sprzeciw wobec robienia użytku z tematu Zagłady do celu w podtrzymywania politycznych tendencji. Musimy akcentować to, że Szoa postrzegamy jako najwyższej wagi środek przekazywania wartości wychowawczych [...] przeciwnych zazdrości i politycznemu mitowi, a zatem przeciwnych łączeniu świętości z kategorią politycznego państwa.

Wajs konkluduje następnie: „Szkoda, że autorka zadowoliła się przywołaniem tych słów dla samego ich przywołania, zamiast napisać w ich duchu swoją książkę. [...] Być może miałaby [wówczas -J.B..] więcej wątpliwości co do wartości tworzenia na siłę «historii Szoa, w której znajdzie się miejsce dla każdego»" (Wajs 209).

Choć, jak pisze Jablonka, pamięć o Zagładzie uległa upowszechnieniu (Jablonka 297), nie stała się przez to pamięcią wspólną i jednolitą dla całego społeczeństwa, a przy tym wciąż powraca pytanie o powody tego upowszechnienia. Uczynienie z pamięci Szoa fundamentalnego doświadczenia całego społeczeństwa wiąże się z nieuchronnym wyparciem innych doświadczeń, niemożliwych do opowiedzenia przy pomocy tych samych pojęć i narzędzi, niemożliwych do zrozumienia na drodze tych samych schematów myślowych. Obraz, który wyłania się z omówionych tutaj kulturowych reprezentacji zderzenia Mizrachim z pamięcią o Zagładzie, zdających się bez wyjątku wyrastać z tej kolizji, utwierdza w przekonaniu, że grupa ta nadal znajduje się na marginesie, którego linię przekroczyć można (częstokroć i tak nie w pełni) wyłącznie za sprawą identyfikacji z doświadczeniem Szoa. Przykłady tych, którzy podjęli wysiłek wpisania się w doświadczenie zbiorowej pamięci, wskazują, że choć historia jest powszechnie dostępna, nie jest i nie może stać się historią wspólną. Choć wszechobecność zagładowego dyskursu w Izraelu

14 W 1977 roku do władzy doszła w Izraelu prawicowa partia Likud. 
zdołała uaktywnić postpamięciowe mechanizmy również (a niekiedy wręcz szczególnie) u tych, których z doświadczeniem Szoa nie łączy rodzinny związek, nie zdołała wyeliminować podziałów przebiegających wewnątrz tej w y o b r a ż o n e j w s pólnoty pamięci (por. Anderson). Być może dzieje się tak dlatego, że nie została ona dotąd skonstruowana od nowa i opowiedziana polifonicznie - w wersji, w której niesłyszalne dotąd głosy dobywałyby się ze środka, nie zaś z marginesów.

\section{BIBLIOGRAFIA}

\section{Literatura podmiotu}

Avni-Levi, Yosi. Isz le-lo cel. Or Jehuda: Zmora-Bitan, 2007.

Avni-Levi, Yosi. Szirat ha-chata'im. Or Jehuda: Zmora-Bitan, 2010.

Chasan, Roj. „Medinat Aszkenaz”. Ha-klawim sze-nawchu be-jaldutenu haju chasumej pe. Tel Awiw: Tangier, 2014. S. 46-63.

Keret, Etgar. Buty. Tęskniąc za Kissingerem. Przeł. Agnieszka Maciejowska. Warszawa: W.A.B., 2008. S. $98-101$.

Sukari, Josi. Bengazi - Bergen-Belsen. Tel Awiw: iCast, 2013.

\section{Wideo}

"Am sgula", Polin: Josi we-Josi. Ha-sipur ha-male; Ha-Germanim hefsidu; Aszrej ha-gafrur; Ba-Szo'a lo haja Facebook; Josi we-Josi pogszim et Josi, Aruc 2, 2011.

Tlalim, Aszer. Al tig'u li ba Szo'a, 1994.

\section{Literatura przedmiotu}

Abramovich, Dvir. Back to the Future. Israeli Literature of the 1980s and the 1990s. Newcastle upon Tyne: Cambridge Scholars, 2011.

Anderson, Benedict. Wspólnoty wyobrażone. Rozważania o źródtach i rozprzestrzenianiu się nacjonalizmu. Przeł. Stefan Amsterdamski. Kraków: Społeczny Instytut Wydawniczy Znak. Warszawa: Fundacja im. Stefana Batorego, 1997.

Bar-On, Dan. Al ha-'acherim' be-tochenu. Tmurot ba-zehut ha-israelit mi-nekudat re'ut psichologit-chewratit. Beer Szewa: Hoca'at ha-Sfarim szel Universitat Ben-Gurion ba-Negew, 2005.

Bartov, Omer. The "Jew" in cinema. From „The Golem" to „Don't Touch My Holocaust”. Bloomington: Indiana University Press, 2005.

Cimerman, Mosze. Al tig'u li ba-Szo'a. Haszpa'at ha-Szo'a al kolno'a we-ha-chewra ha-israelit. Hajfa-Lod: Hoca'at ha-Sfarim szel Uniwersitat Hajfa/ Zmora-Bitan, 2002.

DellaPergola, Sergio. "«Sephardic and Oriental» Jews in Israel and Western Countries: Migration, Social Change and Identification". Studies in Contemporary Jewry. An Anual XXII. Sephardic jewry and Mizrahi Jews (2007). S. 3-43.

Feldman, Jackie. Above the Death Pits, Beneath the Flag. Youth Voyages to Poland and the Performance of Israeli National Identity. New York: Berghahn Books, 2008. 
Jablonka, Hana. Ha-rechek me-ha-mesila. Ha-mizrachim we-ha-Szo'a. Tel Awiw: Jedi'ot acharonot: sifrej hemed/ Machon Ben-Gurion le-Cheker Isra' eli'ut we-ha-Cijonut, Uniwersitat Ben-Gurion ba-Negew, 2008.

Oppenheimer, Yochai. "Representation of Space in Mizrahi Fiction". Transl. Haim Watzman. Hebrew Studies 53 (2012). S. 335-364.

Raz-Krakotzkin, Amnon. “Galut be-toch ribbonut. Le-bikoret "szelilat ha-galut” be-tarbut ha-israelit. Chelek szeni". Tarbut u-wikoret 5 (Staw 1994). S. 113-132

Skalska, Tamara. „Pamięć Protetyczna”. Modi memorandi. Leksykon kultury pamięci. Red. M. Saryusz-Wolska, R. Traba. Warszawa: Wydawnictwo Naukowe Scholar, 2014. S. 343-346.

Shochat, Ella. „Mizrachim be-Israel: ha-cijonut me-nekudat mabat szel korbanotejha ha-jehudim”. Ha-mahapecha ha-mizrachit. Jeruszalajim: Merkaz le-Informacja Alternatiwit, 1999. S. 11-63.

Shochat, Ella. „Taboo Memories, Diasporic Visions. Columbs, Palestine and Arab-Jews”. Taboo Memories, Diasporic Voices. Durham: Duke University Press, 2006. S. 201-232.

Sztejr-Liwni, Liat. Har ha-zikaron izkor bi-mkomi. Ha-zikaron ha-chadasz szel ha-Szo'a be-tarbut ha-popularit be-Israel. Tel Awiw: Resling, 2014.

Wajs, Ifaat. „Nicachon ha-perus szel politikat ha-zehut”. Israel 15 (2009). S. 205-209.

Zertal, Idith. Naród i śmierć. Zagłada w dyskursie i polityce Izraela. Przeł. Jan Maria Kłoczowski. Kraków: Universitas, 2010.

\section{Źródła internetowe}

Szimoni, Batja. „Lihijot Mizrachi, laga'at ba-Szo'a, lihijot Aszkenazi”. 2014. Web. 05.02.2016.<www. haokets.org/.../ארשי-תויהל-האושב-תעגל-יחרזמ-תויהל >

Taharlew, Itamar Tobi. „Katriliewke ha-chadasza”. 2012. Web. 16.02.2016. <https://haemori.wordpress. com/2012/04/19/holocaus/> 